\section{Response of Six Bermudagrass Cultivars to Different Irrigation Intervals}

\author{
C.M. Baldwin ${ }^{1}$, H. Liu ${ }^{1,3}$, L.B. McCarty ${ }^{1}$, W.L. Bauerle ${ }^{1}$, and \\ J.E. Toler ${ }^{2}$
}

ADDITIONAL INDEX WORDs. drought resistance, Cynodon spp., water, evapotranspiration, volumetric soil water content, turfgrass quality, rooting, turfgrass

\begin{abstract}
SUMMARY. A 2-year greenhouse study was conducted at Clemson University, Clemson, S.C., in 2003 and 2004 to determine drought responses of six bermudagrass (Cynodon spp.) cultivars at four irrigation intervals. Cultivars selected from the 2002 National Turfgrass Evaluation Program Bermudagrass Trial were 'SWI-1012', 'Arizona Common', 'Tift No.3', 'Tifsport', 'Aussie Green', and 'Celebration'. Treatments included 5-, 10-, and 15-day irrigation intervals plus a control (irrigated daily). Volumetric soil water content (VSWC) and evapotranspiration (ET) rates were recorded every 3 days. Turfgrass quality (TQ) was observed weekly and root weight was measured at the end of a 6-week study. 'Aussie Green' and 'Celebration' produced the highest TQ rating (>7) at week 4 when watered daily. After 4 weeks of the 5-day irrigation interval, all cultivars showed unacceptable quality ratings $(<7)$. However, 'Aussie Green' and 'Celebration' were able to maintain an acceptable TQ rating (7), compared to 'Arizona Common' (5.1) and 'Tift No.3' (5.8) at week 2 (5-day treatment). 'Celebration' produced $114 \%$ and $97 \%$ greater root weight than 'Tifsport' and 'Aussie Green', respectively, when pooled across all irrigation treatments. At the 15-day irrigation interval treatment, six bermudagrass cultivars pooled together produced $78 \%, 22 \%$, and $11 \%$ greater root weight vs. control, 5 -day, and 10 -day treatments, respectively. When pooled for all treatments, 'Aussie Green' and 'Celebration' VSWC was 5\% and 7\% lower than 'Tift No.3', and ET rates were $26 \%$ and $30 \%$ greater than 'Arizona Common'. Based on these results, irrigating bermudagrass in 5-day intervals should be carefully monitored.
\end{abstract}

$\mathrm{W}$ ater use is the primary input required for growth and survival of turfgrasses ( $\mathrm{Mc}$ Carty, 2005). Turfgrass plants contain between $75 \%$ to $85 \%$ water by weight (Beard, 1966) and begin to wilt with a $10 \%$ decrease in water content (Beard, 1973). Although bermudagrasses are adapted to many soil and hot climatic regions and regarded as a droughttolerant species (McCarty and Miller, 2002), adequate soil moisture is required to sustain proper growth, color, and shoot density (Taliaferro, 2003). Therefore, selection of cultivars requiring less moisture with fewer irrigation and water requirements has become an important issue in turfgrass management (Kim and Beard, 1988).

Evapotranspiration water losses by turfgrasses are significant and

\footnotetext{
Clemson University, Clemson, SC 29634-0314.

${ }^{1}$ Department of Horticulture D-136 Poole Ag. Center.

${ }^{2}$ Department of Applied Economics and Statistics.

${ }^{3}$ Corresponding author: haibol@clemson.edu
}

determined by wind velocity, relative humidity $(\mathrm{RH})$, air temperature, soil temperature, and turfgrass species (Kim and Beard, 1988). Also, soil structure and texture impact ET rates and plant water use efficiency. For example, soil with high clay content has more micropores, allowing slow gas and water movement, while sandy soils contain more macropores, allowing air and percolating water to move freely through the soil profile (Brady and Weil, 1996). Hence, irrigation rates should be adjusted based on soil type and turfgrass species. Also, irrigation timing is important in water use efficiency. Midday irrigation is inefficient due to high ET loss, while night irrigation most efficiently satisfies plant water needs, although disease problems may increase (Turgeon, 2005).

Differences in drought resistance in warm-season and cool-season turfgrasses have been reported and studied intensively (Hook and Hanna, 1994; Jiang et al., 1998; Karsten and MacAdam, 2001; Kim and Beard, 1988; Schann et al., 2003). Using irrigation intervals to enhance TQ and rooting of several turfgrasses have been reported. Jordan et al. (2003) noted creeping bentgrass (Agrostis stolonifera) TQ and root and shoot length densities were greatest using a 4-d irrigation interval. Jordan et al. (2005) indicated TQ of creeping bentgrass putting surface irrigated in $4-\mathrm{d}$ irrigation intervals was superior to a daily irrigating regime. When reducing irrigation, plants produce larger and deeper root systems, resulting in higher quality turfgrass (Qian et al., 1997). A reduction in irrigation frequency also preconditions the plant to adapt to lower water potential conditions (Jordan et al., 2005). Richie et al. (2002) noted TQ improvement for mature stand of tall fescue (Festuca arundinacea) when irrigated deeply and less frequently. In an attempt to reduce irrigation frequency, Brown et al. (2004) observed that irrigating tall fescue twice weekly had no significant effect on soil moisture status, yield, color, or cover ratings. Employing this irrigation strategy would lead to 100 $\mathrm{d}$ saved during peak irrigation months of May through October. Schaan et al. (2003) noted no significant color or cover loss of 'Tifway' bermudagrass or 'Champion' perennial ryegrass ( $L 0^{-}$ lium perenne) by cycling fresh water with saline groundwater of $3.3 \mathrm{dS} \cdot \mathrm{m}^{-1}$. Also, fresh water savings of 4.3 to 19.6 inches were noted as saline treatments increased. The cyclic irrigation strategy allowed up to $62 \mathrm{~d}$ more of water use during peak demanding months.

\begin{tabular}{llll}
\hline $\begin{array}{l}\text { Units } \\
\begin{array}{l}\text { To convert U.S. to SI, } \\
\text { multiply by }\end{array}\end{array}$ & U.S. unit & SI unit & $\begin{array}{l}\text { To convert SI to U.S., } \\
\text { multiply by }\end{array}$ \\
\hline 2.54 & inch(es) & $\mathrm{cm}$ & 0.3937 \\
25.4 & inch(es) & $\mathrm{mm}$ & 0.0394 \\
16.3871 & inch & $\mathrm{cm}^{3}$ & 0.0610 \\
1.1209 & $\mathrm{lb} / \mathrm{acre}^{3}$ & $\mathrm{~kg} \cdot \mathrm{ha}^{-1}$ & 0.8922 \\
0.5933 & $\mathrm{lb} / \mathrm{yard}{ }^{3}$ & $\mathrm{~kg} \cdot \mathrm{m}^{-3}$ & 1.6856 \\
1 & $\mathrm{meq} / 100 \mathrm{~g}$ & $\mathrm{cmol} \cdot \mathrm{kg}^{-1}$ & 1 \\
1 & mmho $/ \mathrm{cm}$ & $\mathrm{dS} \cdot \mathrm{m}^{-1}$ & 1 \\
28.3495 & oz & $\mathrm{g}$ & 0.0353 \\
$\left({ }^{\circ} \mathrm{F}-32\right) \div 1.8$ & ${ }^{\circ} \mathrm{F}$ & ${ }^{\circ} \mathrm{C}$ & $\left(1.8 \times{ }^{\circ} \mathrm{C}\right)+32$ \\
& & &
\end{tabular}


The development of droughtresistant turfgrass has become an important issue in golf course management, and one key objective of turfgrass breeding and improvement is to develop drought-resistant turfgrasses (Hanna, 1998). Scientists at the Southeastern Turf Research Center at Tifton, Ga., state one major objective of their triploid hybrid bermudagrass breeding program is the development of hybrids that produce acceptable TQ 1998). Bermudagrasses differ greatly in both geographical distribution and the magnitude of genetic variation (Taliaferro, 1995), which promises a great potential for future improvement, including drought resistance (Hanna, 1998; Taliaferro, 1995, 2003 ). Identification of bermudagrass cultivars with superior drought resistance and variability among cultivars will benefit turfgrass breeding programs and practitioners in cultivar selection. Therefore, the objective of this greenhouse study was to quantify drought resistance of six bermudagrass cultivars in response to daily, 5-, 10-, and 15 -d irrigation intervals by monitoring $\mathrm{TQ}$, root weight, $\mathrm{ET}$, and soil moisture status.

\section{Materials and methods}

A 30-d greenhouse study was conducted at Clemson University, Clemson, S.C., in 2003 and repeated in 2004 (Table 1). Year I was conducted from I July to 13 Aug. 2003 with greenhouse conditions averaging $27 / 19^{\circ} \mathrm{C}$ high/low air temperature and $67 \% \mathrm{RH}$. Year II was conducted from 28 May to 4 July 2004 with greenhouse conditions maintained with an with minimal irrigation input (Hanna,

average high/low air temperature of $29 / 23^{\circ} \mathrm{C}$ and $72 \% \mathrm{RH}$.

This study consisted of four irrigation interval treatments of 5-, 10-, and 15-d irrigation intervals plus a control (irrigated daily). After each irrigation interval, the soil was saturated and allowed to freely drain. All cultivars were uniformly grown and maintained in lysimeters 6 inches in diameter and 18 inches high filled with 4 inches of gravel $(8-10 \mathrm{~mm}$ in diameter) and 12 inches of sandy loam topsoil (Table 2). The lysimeters were made of polyvinyl chloride (PVC) pipes with a bottom drainage hole of $6 \mathrm{~mm}$. Soil was collected from the Clemson University athletic practice fields during renovations in May 2000. Plugs of sod were collected from the 2002 National Turfgrass Evaluation Program (NTEP) bermudagrass trials at the Clemson University Research Center, washed free of soil with roots clipped and allowed to establish for 30 $\mathrm{d}$ before treatment initiation. Lysimeters were moved weekly to eliminate any location effects in the greenhouse. Each cultivar received nitrogen at 48.8 $\mathrm{kg} \cdot \mathrm{ha}^{-1}$ every 2 weeks using a complete fertilizer $(16 \mathrm{~N}-1.7 \mathrm{P}-6.6 \mathrm{~K})$ with a slow-release urea and micronutrients: $6 \mathrm{~kg} \cdot \mathrm{ha}^{-1}$ calcium, $3 \mathrm{~kg} \cdot \mathrm{ha}^{-1}$ magnesium, $9 \mathrm{~kg} \cdot \mathrm{ha}^{-1}$ sulfur, $0.06 \mathrm{~kg} \cdot \mathrm{ha}^{-1}$ boron, $0.03 \mathrm{~kg} \cdot \mathrm{ha}^{-1}$ copper, $0.3 \mathrm{~kg} \cdot \mathrm{ha}^{-1}$ iron, $0.15 \mathrm{~kg} \cdot \mathrm{ha}^{-1}$ manganese, 0.0015 $\mathrm{kg} \cdot \mathrm{ha}^{-1}$ molybdenum, and $0.15 \mathrm{~kg} \cdot \mathrm{ha}^{-1}$ zinc. All turfgrasses were mowed every other day at a height of 1 inch with clippings removed.

Data collection. Data collection for years I and II was identical. VSWC was measured in the top 6 inches and recorded daily between

Table 1. Bermudagrass cultivars selected for a greenhouse study to evaluate drought resistance.

\begin{tabular}{|c|c|c|c|}
\hline Cultivar $^{\mathrm{z}}$ & Propagation & $\begin{array}{l}\text { Cultivar } \\
\text { sources }^{\mathrm{y}}\end{array}$ & Scientific name \\
\hline SWI-1012 & Seeded & Seeds West & Cynodon dactylon \\
\hline Arizona Common & Seeded & standard entry ${ }^{x}$ & C. dactylon \\
\hline Tift No. 3 & Vegetative & W. Hanna & C. dactylon $\times$ C. transvaalensis \\
\hline Tifsport & Vegetative & standard entry & C. dactylon $\times$ C. transvaalensis \\
\hline \multicolumn{4}{|l|}{ Aussie } \\
\hline Green & Vegetative & $\begin{array}{c}\text { Greg Norman } \\
\text { Turf Co. }\end{array}$ & C. dactylon $\times$ C. transvaalensis \\
\hline Celebration & Vegetative & Sod Solutions & C. dactylon $\times$ C. transvaalensis \\
\hline \multicolumn{4}{|c|}{$\begin{array}{l}{ }^{2} \text { Cultivars selected from the } 2002 \text { National Turfgrass Evaluation Program field research plots at Clemson Uni- } \\
\text { versity, Clemson, S.C. } \\
\text { 'Seeds West, Yuma, Ariz.; W. Hanna, U.S. Department of Agriculture, Agricultural Research Service, University } \\
\text { of Georgia, Coastal Plain Experiment Station,Tifton; Greg Norman Turf Co., Avon Park, Fla.; Sod Solutions, } \\
\text { Mt. Pleasant, S.C. }\end{array}$} \\
\hline
\end{tabular}

1130 and 1330 HR using a timedomain reflectometer (model ML2; Delta-T Devices Ltd., Cambridge, U.K.) soil moisture sensor. TQ ratings were recorded weekly based on color, density, texture, and uniformity of the bermudagrass surface (Bunnell et al., 2005). Quality was rated from 1 to 9 , where 1 = brown, dead turfgrass; $7=$ minimal acceptable turfgrass; and 9 = perfect green, healthy turfgrass . ET rates were calculated using a scale (model PC-220; Greenville Scale Co., Greenville, S.C.) to weigh each lysimeter every third day between 1230 and $1300 \mathrm{HR}$ to determine water loss. At the end of the study, roots were extracted from soil and thoroughly washed until all soil was removed. Roots were then separated from shoot tissues, oven dried at $176.0^{\circ} \mathrm{F}$ for $48 \mathrm{~h}$, and weighed for total root weight.

Data Analysis. Treatments were arranged in a randomized completeblock design with four replications. All data were subjected to analysis of variance (SAS version 8.0; SAS Institute, Cary, N.C.). Data from both years were combined, as year I $\times$ year II interactions were nonsignificant. Interactions for TQ were significant and means were separated by Fisher's least significant difference (LSD) test at $P \leq 0.05$ (Shearman et al., 2005). However, interactions for root weight, VSWC, and ET were nonsignificant at $P \leq 0.05$; therefore, main effect means for cultivar and treatment effects are reported (Table 3 ).

Table 2. Chemical and physical properties of the sandy loam soil collected from the Clemson University (Clemson, S.C.) athletic practice fields in May 2002.

\begin{tabular}{lr}
\hline $\begin{array}{l}\text { Parameters } \\
\text { measured }\end{array}$ & Sandy loam soil ${ }^{\mathbf{z}}$ \\
\hline Soil pH & 6.8 \\
Cation exchange & \\
$\quad$ capacity & $12.9 \mathrm{meq} / \mathrm{l} 00 \mathrm{~g}$ \\
Organic matter & $3.6 \%$ \\
Bulk density & $1848 \mathrm{lb} /$ yard $^{3}$ \\
Phosphorus & $140 \mathrm{lb} /$ acre $^{2}$ \\
Potassium & $111 \mathrm{lb} /$ acre \\
Calcium & $4140 \mathrm{lb} /$ acre \\
Magnesium & $387 \mathrm{lb} /$ acre \\
Zinc & $8.9 \mathrm{lb} /$ acre \\
Manganese & $47 \mathrm{lb} /$ acre \\
Copper & $0.4 \mathrm{lb} /$ acre \\
Boron & $1.1 \mathrm{lb} /$ acre \\
Sodium & $11 \mathrm{lb} /$ acre
\end{tabular}

${ }^{2} 1 \mathrm{meq} / 100 \mathrm{~g}=1 \mathrm{cmol} \cdot \mathrm{kg}^{-1} ; \mathrm{l} \mathrm{lb} / \mathrm{yard}^{3}=0.5425$ $\mathrm{kg} \cdot \mathrm{m}^{3} ; 1 \mathrm{lb} / \mathrm{acre}=1.1209 \mathrm{~kg} \cdot \mathrm{ha}^{-1}$. 


\section{Results and discussion}

Turfgrass Quality. 'Aussie Green' (7.0) and 'Celebration' (7.0) maintained an acceptable TQ rating (>7) at week 2 (5-d treatment) compared to 'Arizona Common' (5.1), 'Tift No.3' (5.8), and 'TifSport' (6.0) (Table 4). Results disagree with previous research that TQ increases as turfgrass is irrigated in intervals rather than daily. Jordan et al. (2003) noted an increase in TQ as bentgrass cultivars were irrigated in 4 -d intervals compared to daily irrigation. Also, Johnson (2003) stated TQ was greatest when kentucky bluegrass (Poa pratensis), tall fescue, prairie junegrass (Koeleria macrantha), and buffalograss (Buchloe dactyloides) were irrigated in 2-d intervals compared to 4- and 6-d intervals. The previous two experiments were field studies; therefore, the turfgrass may have access to additional water in the soil profile. Also, it might be possible that water stress intervals were less severe.

At the 10- and 15-d irrigation intervals, all cultivar TQ scores were unacceptable $(<7)$ by week I (Table $5)$. Results indicate that irrigating in 5 -d intervals negatively affects TQ; however, results may differ in a field study as the turfgrass could access water deep in the soil profile.

Root WEIGHT. Cultivar and treatment main effect means are reported for root weight. After 4 weeks of various irrigation intervals, 'Celebration' produced $114 \%$ and $65 \%$ greater root weight than 'Tifsport' and 'Aussie Green'. Also, 'SWI-1012' had 97\% and $52 \%$ greater root weight than 'Tifsport' and 'Aussie Green' when pooled across all treatments (Fig. 1).

The 15-d treatment of all bermudagrass cultivars pooled together produced $78 \%, 22 \%$, and $11 \%$ greater root weight than control, 5 -d, and 10-d treatments, respectively (Fig. 2). This was expected as root length and growth increase as water becomes limited. The main function of a root is to intercept water and nutrients. As water decreases, roots continue downward movement in the soil profile in search of water. Johnson (2003) reported prairie junegrass root system absorbed water at a depth of 12 inches when irrigated between 4- to 6-d intervals. Bonos and Murphy (1999) also noted an increase in kentucky bluegrass cul-

Table 3. Significance of variances for bermudagrass cultivars turfgrass quality (TQ), root weight (RW), volumetric soil water content (VSWC), and evapotranspiration rates (ET).

\begin{tabular}{lcccc}
\hline Source & TQ & RW & VSWC & ET \\
\hline Cultivar (C) & $* * * *$ & $* * *$ & $* * *$ & $* * * *$ \\
Irrigation (I) & $* * * *$ & $* * *$ & $* * * *$ & $* *$ \\
Rating date (RD) & $* * * *$ & --- & $*$ & $*$ \\
$\mathrm{C} \times \mathrm{I}$ & $* * *$ & $\mathrm{NS}$ & $*$ & $*$ \\
$\mathrm{C} \times \mathrm{RD}$ & $* * *$ & --- & $\mathrm{NS}$ & $\mathrm{NS}$ \\
$\mathrm{I} \times \mathrm{RD}$ & $* * *$ & --- & $\mathrm{NS}$ & $\mathrm{NS}$ \\
$\mathrm{C} \times \mathrm{I} \times \mathrm{RD}$ & $\mathrm{NS}$ & -- & $\mathrm{NS}$ & $\mathrm{NS}$ \\
${ }_{\mathrm{NS}, *}^{* * * * * * * * * *}$ Nonsignificant or significant at $P \leq 0.10,0.05,0.01,0.001$, respectively.
\end{tabular}

Table 4. Turfgrass quality of each selected bermudagrass cultivar recorded weekly following daily and 5-d watering intervals.

\begin{tabular}{|c|c|c|c|c|c|c|c|c|}
\hline \multirow{2}{*}{$\begin{array}{l}\text { Bermudagras } \\
\text { cultivars }\end{array}$} & \multicolumn{4}{|c|}{ Daily } & \multicolumn{4}{|c|}{ 5-d Intervals } \\
\hline & Week 1 & Week 2 & Week 3 & Week 4 & Week 1 & Week 2 & Week 3 & Week 4 \\
\hline & & & Turtg & quan & $1-70$ & 4) & & 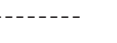 \\
\hline SWI 1012 & $6.9 \mathrm{bc}^{\mathrm{y}}$ & $7.3 \mathrm{a}$ & $7.1 \mathrm{ab}$ & $7.0 \mathrm{a}$ & $5.8 \mathrm{c}$ & $6.6 \mathrm{ab}$ & $6.1 \mathrm{a}$ & 6.1 \\
\hline Arizona & & & & & & & & \\
\hline Common & $5.9 \mathrm{~d}$ & $6.4 \mathrm{~d}$ & $6.1 \mathrm{c}$ & $6.3 \mathrm{~b}$ & $5.0 \mathrm{c}$ & $5.1 \mathrm{c}$ & $4.9 \mathrm{~b}$ & 5.3 \\
\hline Tift No.3 & $6.8 c$ & $7.0 \mathrm{bc}$ & $6.9 \mathrm{ab}$ & $6.8 \mathrm{ab}$ & $6.5 \mathrm{bc}$ & $5.8 \mathrm{bc}$ & $5.9 \mathrm{~b}$ & 5.8 \\
\hline Tifsport & $6.6 \mathrm{c}$ & $6.6 \mathrm{~cd}$ & $6.8 \mathrm{~b}$ & $7.1 \mathrm{a}$ & $6.0 \mathrm{bc}$ & $6.0 \mathrm{bc}$ & $6.1 \mathrm{a}$ & 6.0 \\
\hline Aussie Green & $7.5 \mathrm{ab}$ & $7.5 \mathrm{ab}$ & $7.3 \mathrm{ab}$ & $7.4 \mathrm{a}$ & $6.9 \mathrm{ab}$ & $7.0 \mathrm{a}$ & $6.8 \mathrm{a}$ & 6.5 \\
\hline Celebration & $7.6 \mathrm{a}$ & $7.8 \mathrm{a}$ & $7.4 \mathrm{a}$ & $7.4 \mathrm{a}$ & $7.1 \mathrm{a}$ & $7.0 \mathrm{a}$ & $6.8 \mathrm{a}$ & 6.5 \\
\hline $\mathrm{LSD}^{\mathrm{y}}$ & 0.71 & 0.55 & 0.56 & 0.76 & 1.11 & 0.94 & 1.19 & 0.90 \\
\hline$P$ & 0.01 & 0.01 & 0.01 & 0.03 & 0.01 & 0.01 & 0.03 & 0.06 \\
\hline
\end{tabular}

${ }^{\mathrm{z}} 1$ = brown/dead turfgrass; 7 = minimally acceptable turfgrass; 9 = healthy/green turfgrass.

yalues within a column followed by the same letter are not significantly different at Fisher's least significant difference (LSD) test at $P \leq 0.05$.

Table 5. Turfgrass quality of each selected bermudagrass cultivar recorded weekly following 10-d and 15-d watering intervals.

\begin{tabular}{|c|c|c|c|c|c|c|c|c|}
\hline \multirow{2}{*}{$\begin{array}{l}\text { Bermudagras } \\
\text { cultivars }\end{array}$} & \multicolumn{4}{|c|}{$10 \mathrm{~d}$} & \multicolumn{4}{|c|}{$15 \mathrm{~d}$} \\
\hline & Week 1 & Week 2 & Week 3 & Week 4 & Week 1 & Week 2 & Week 3 & Week 4 \\
\hline & & & - Turfgr & ss quality & (1-9 scale & $e)^{z}-----$ & & ---- \\
\hline SWI 1012 & 6.3 & 6.4 & 5.1 & $4.8 \mathrm{a}^{\mathrm{y}}$ & $6.4 \mathrm{ab}$ & $5.6 \mathrm{a}$ & 5.3 & 3.8 \\
\hline Arizona & & & & & & & & \\
\hline Common & 5.8 & 5.0 & 4.4 & $3.0 \mathrm{~b}$ & $4.8 \mathrm{c}$ & $4.0 \mathrm{~b}$ & 3.9 & 2.6 \\
\hline Tift No.3 & 5.6 & 5.6 & 5.3 & $5.1 \mathrm{a}$ & $5.5 \mathrm{abc}$ & $5.4 \mathrm{a}$ & 4.8 & 4.3 \\
\hline Tifsport & 5.9 & 6.3 & 5.5 & $5.6 \mathrm{a}$ & $5.3 \mathrm{bc}$ & $4.8 \mathrm{ab}$ & 4.3 & 4.4 \\
\hline Aussie Green & 6.1 & 6.0 & 5.5 & $4.6 \mathrm{a}$ & $6.5 \mathrm{a}$ & $5.8 \mathrm{a}$ & 5.3 & 4.0 \\
\hline Celebration & 6.9 & 6.5 & 6.0 & $4.8 \mathrm{a}$ & $6.4 \mathrm{ab}$ & $5.7 \mathrm{a}$ & 5.4 & 3.8 \\
\hline $\operatorname{LSD}^{\mathrm{y}}$ & 1.22 & 1.11 & 1.32 & 1.18 & 1.13 & 1.04 & 1.21 & 1.28 \\
\hline$P$ & 0.36 & 0.08 & 0.26 & 0.01 & 0.01 & 0.01 & 0.08 & 0.10 \\
\hline
\end{tabular}

tivar root growth as drought stress was imposed.

VOLUMETRIC SOIL WATER CONTENT. Interactions for VSWC were not observed; therefore, cultivar effect results were pooled (Fig. 3). While 'Aussie Green' and 'Celebration' produced the greatest TQ (Table 4), VSWC was $5 \%$ and $7 \%$ lower than 'Tift No.3' (Fig. $3)$. This may be due to the greater root weight of 'Celebration' as it extracted more water than 'Tift No.3'; however, 'Tift No.3' produced $42 \%$ greater root weight than 'Aussie Green' (Fig. 1). Bonos and Murphy (1999) reported stress-tolerant kentucky bluegrass cultivars are able to extract more water at 6- to 12 -inch depths.

Evapotranspiration. Statistical differences were observed for ET rates 


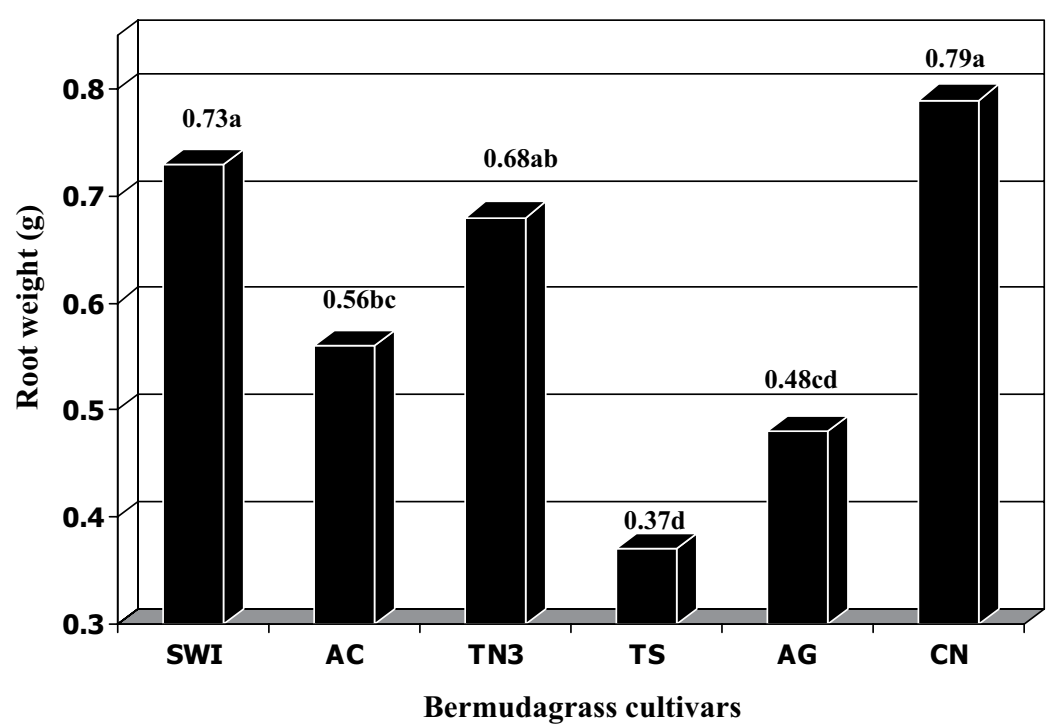

Fig. 1. Comparison of six bermudagrass cultivars in root weight with data from each treatment (daily, 5-d, 10-d, and 15-d irrigation intervals) pooled together. Mean data points followed by the same letter are not significantly different at Fisher's least significant difference test at $P \leq 0.05$. SWI = 'SWI-1012', AC = 'Arizona Common', TN3 = 'Tift.No3', TS = 'Tifsport', AG = 'Aussie Green', CN $=$ 'Celebration' $(1 \mathrm{~g}=0.0353 \mathrm{oz})$.

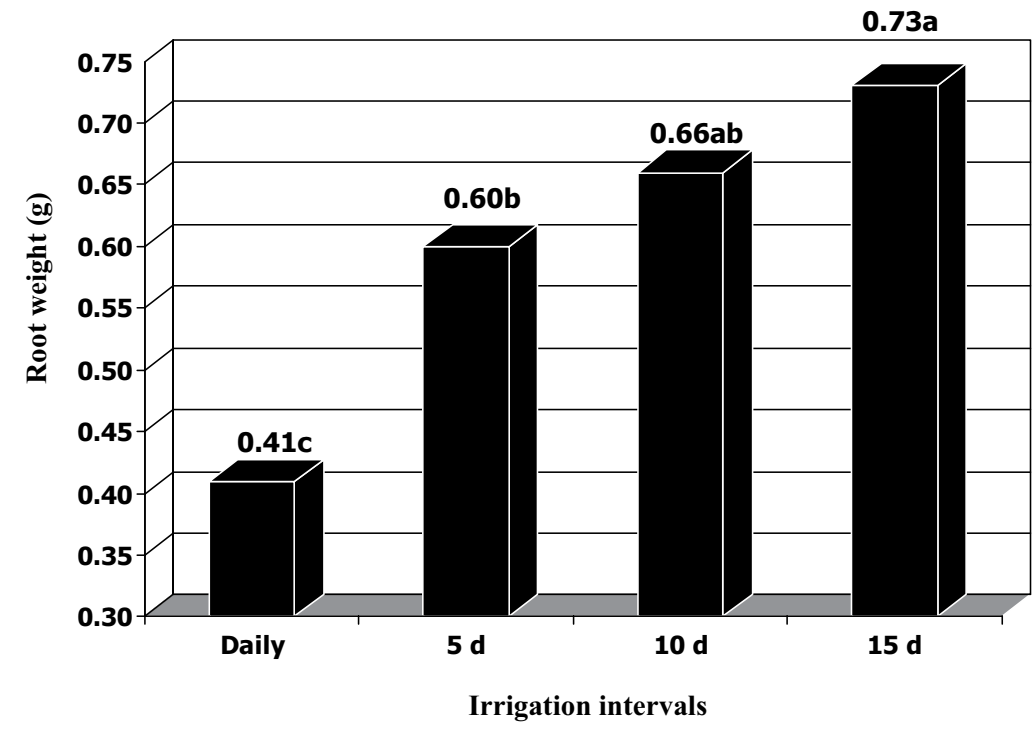

Fig. 2. Root weight of six combined bermudagrass cultivars with data from each cultivar ('SWI-1012,' 'Arizona Common', 'Tift.No3', 'Tifsport', 'Aussie Green', and 'Celebration') pooled together. Mean data points followed by the same letter are not significantly different at Fisher's least significant difference test at $P \leq$ $0.05(1 \mathrm{~g}=0.0353 \mathrm{oz})$.

recorded every $3 \mathrm{~d}$ (Fig. 4 ) during the study. When pooled across all irrigation interval treatments, 'Celebration' and 'Aussie Green' had 30\% and 26\% greater ET than 'Arizona Common'. Highest ET (Fig. 4) and lowest VSWC (Fig. 3) for 'Aussie Green' and 'Celebration' indicate these cultivars may extract a greater amount of water from the soil profile and increase evaporative cool- ing. Also, these data may indicate these cultivars undergo a greater osmotic adjustment, leading to an enhanced response to drought compared to the other four cultivars. Morphological differences such as leaf texture, shoot density, and leaf orientation also play a role in ET among turfgrasses (Kim and Beard, 1988). However, further investigations on water potential and morphological characteristics among these cultivars are needed.

\section{Conclusion}

This greenhouse study tested the drought response and influence of irrigation intervals and identified genetic diversity among the selected six bermudagrass cultivars. Only two cultivars, 'Aussie Green' and 'Celebration', had acceptable TQ at the 5-d treatment after 2 weeks in a greenhouse environment. At the same treatment ( $5 \mathrm{~d}$ ) by week 3 , a reduction in TQ was observed for 'Arizona Common' (5.1) and 'Tift No.3' (5.8). As drought stress was imposed longer than the 5 -d interval, all cultivars quickly declined in TQ. This may indicate irrigating in $\mathrm{ex}$ tended intervals $(>5 \mathrm{~d})$ is not adequate moisture to sustain acceptable bermudagrass quality at a mowing height of 1 inch. 'Celebration' produced superior rooting with a $114 \%$ increase compared to 'Tifsport' and as drought intervals increased, root weight increased. The 15 -d treatment produced $78 \%, 22 \%$, and $11 \%$ greater root weight for all six combined cultivars than the control, $5-\mathrm{d}$, and $10-\mathrm{d}$ treatments, respectively. 'Celebration' and 'Aussie Green' had $30 \%$ and 26\% greater ET than 'Arizona Common' while 'Aussie Green' and 'Celebration' showed 5\% and 7\% lower VSWC than 'Tifsport' with all treatments pooled together. Finally, continued screening of bermudagrass cultivars in the greenhouse and field is needed for further enhancement of bermudagrass drought resistance.

\section{Literature cited}

Beard, J.B. 1966. Direct low temperature injury of nineteen turfgrasses. Quarterly Bul. Mich. Agr. Expt. Sta. 48(3):377383.

Beard, J.B. 1973. Turfgrass: Science and culture. Prentice-Hall, Englewood Cliffs, N.J.

Bonos, S.A. and J.A. Murphy. 1999. Growth responses and performance of kentucky bluegrass under summer stress. Crop Sci. 39:770-774.

Brady, N.C. and R.R. Weil. 1996. The nature and properties of soils, llth ed. Prentice-Hall, Upper Saddle River, N.J.

Brown, C.A., D.A. Devitt, and R.L. Morris. 2004. Water use and physiological response of tall fescue to water deficit irrigation in an arid environment. HortScience 39(2):388-393. 


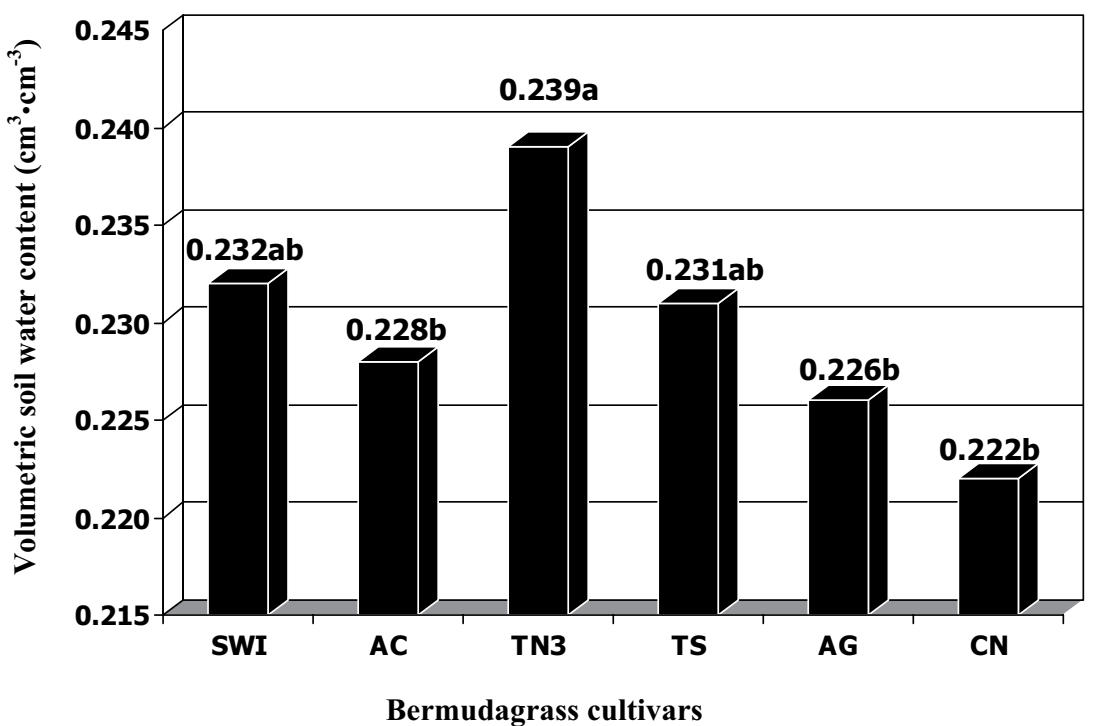

Fig. 3. Comparison of six bermudagrass cultivars in volumetric soil water content with data from each treatment (daily, 5-d, 10-d, and 15-d irrigation intervals) pooled together. Mean data points followed by the same letter are not significantly different at Fisher's least significant difference test at $P \leq 0.05$. SWI = 'SWI-1012', AC = 'Arizona Common', TN3 = 'Tift.No3', TS = 'Tifsport', AG $=$ 'Aussie Green', $\mathrm{CN}=$ 'Celebration' $\left(1 \mathrm{~cm}^{3}=0.0610 \mathrm{inch}^{3}\right)$.

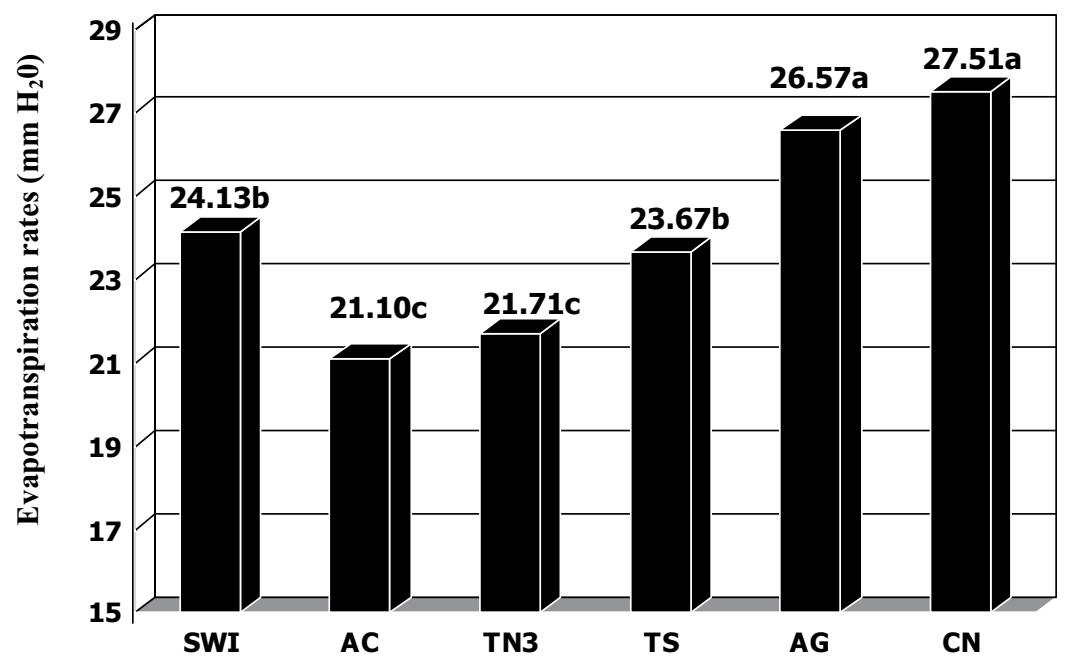

Bermudagrass cultivars

Fig. 4. Comparison of six bermudagrass cultivars in evapotranspiration rates [millimeters of water $\left(\mathrm{H}_{2} \mathrm{O}\right)$ ] every third d with data from each treatment (daily, $5-d, 10-d$, and 15-d irrigation intervals) pooled together. Mean data points followed by the same letter are not significantly different at Fisher's least significant difference test at $P \leq \mathbf{0 . 0 5}$. SWI = 'SWI-1012', AC = 'Arizona Common', TN3 $=$ 'Tift.No3', TS = 'Tifsport', AG ='Aussie Green', CN = 'Celebration' $(1 \mathrm{~mm}=$ 0.0394 inch).

Bunnell, B.T., L.B. McCarty, and W.C. Bridges. 2005. 'TifEagle' bermudagrass response to growth factors and mowing height when grown at various hours of sunlight. Crop Sci. 45:575-581.

Hanna, W.W. 1998. The future of bermudagrass. Golf Course Mgt. 66(9):49-52.
Hook, J.E. and W.W. Hanna. 1994. Drought resistance in centipedegrass cultivars. HortScience 29(12):1528-1531.

Jiang, H., J.D. Fry, and S.C. Wiest. 1998. Variability in turfgrass water requirements on a golf course. HortScience 33(4):689-691.
Johnson, P.G. 2003. The influence of frequent or infrequent irrigation on turfgrasses in the cool-arid west. U.S. Golf Assn. Turfgrass Environ. Res. Online 2:1-8.

Jordan, J.E., R.H. White, J.C. Thomas, T.C. Hale, and D.M. Vietor. 2005. Irrigation frequency effects on turgor pressure of creeping bentgrass and soil air composition . HortScience 40(1):232-236.

Jordan, J.E., R.H. White, D.M. Vietor, T.C. Hale, J.C. Thomas, and M.C. Engelke. 2003. Effect of irrigation frequency on turf quality, shoot density, and root length density of five bentgrass cultivars. Crop Sci. 43:282-287.

Karsten, H.G. and J.W. MacAdam. 2001. Effect of drought on growth, carbohydrates, and soil water use by perennial ryegrass, tall fescue, and white clover. Crop Sci. 41:156-166.

Kim, K.S. and J.B. Beard. 1988. Comparative turfgrass evapotranspiration rates and associated plant morphological characteristics. Crop Sci. 28:328-331.

McCarty, L.B. 2005. Best golf course management practices, 2 nd ed. Prentice-Hall, Upper Saddle River, N.J.

McCarty, L.B. and G. Miller. 2002. Managing bermudagrass turf: Selection, construction, cultural practices and pest management strategies. Sleeping Bear Press, Chelsea, Mich.

Qian, Y.L., J.D. Fry, and W.S. Upham. 1997. Rooting and drought avoidance of warm-season turfgrasses and tall fescue. Crop Sci. 37:905-910.

Richie, W.E., R.L. Green, G.J. Klein, and J.S. Hartin. 2002. Tall fescue performance influenced by irrigation scheduling, cultivar, and mowing height. Crop Sci. 42:2011-2017.

Schaan, C.M., D.A. Devitt, R.L. Morris, and L. Clark. 2003. Cyclic irrigation of turfgrass using a shallow saline aquifer. Agron J. 95(3):660-667.

Shearman, R.C., L.A. Wit, S. Severmutlu, H. Budak, and R.E. Gaussoin. 2005. Colorant effects on dormant buffalograss turf performance. Hort Technology $15(2): 244-246$.

Taliaferro, C.M. 1995. Genetic diversity and vulnerability of bermuda turfgrass species. Crop Sci. 35:327-332.

Taliaferro, C.M. 2003. Bermudagrass, p. 235-256. In: M.D. Casler and R.R. Duncan (eds.). Turfgrass biology, genetics, and breeding. Wiley, Hoboken, N.J.

Turgeon, A.J. 2005. Turfgrass management, 7 th ed. Prentice-Hall, Upper Saddle River, N.J. 